\title{
Market Liquidity and Stock Return in the Nigerian Stock Exchange Market
}

\author{
Ibrahim Bello Abdullahi'; ${ }^{1}$ Segun Kamorudeen Fakunmoju² \\ ${ }^{1}$ Department of Finance, University of Ilorin \\ Ilorin, Kwara State, Nigeria \\ ${ }^{2}$ Department of Finance, Kwara State University \\ Malete, Nigeria \\ 'abibrahim@unilorin.edu.ng; ${ }^{2 k}$.fakunmoju@gmail.com
}

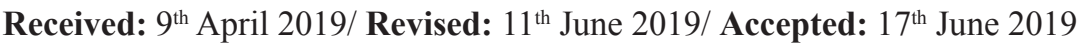

How to Cite: Abdullahi, I. B., \& Fakunmoju, S. K. (2019). Market Liquidity and Stock Return in the Nigerian Stock Exchange Market. Binus Business Review, 10(2), 87-94. https://doi.org/10.21512/bbr.v10i2.5588

\begin{abstract}
This research examined the effect of market liquidity, inflation, and exchange rates on stock return in Nigerian Stock Exchange market. The researchers used ex-post facto design and employed secondary data subjected to Auto-regressive Distributive Lag (ARDL) bound test method of analysis within the period of twenty-one years. Findings reveal that in the short run, stock turnover, trading volume, exchange, and inflation rates have affected stock return positively and significantly. In the long run, market turnover has a positive effect. However, inflation and exchange rates have affected stock return negatively and significantly. Then, trading volume has a negative but insignificant effect on stock return, which is all at 5\% level of significance. The researchers conclude that market liquidity, exchange, and inflation rates affect stock return. Therefore, the researchers recommend demutualization and transparent structures and adaptive method stabilization in exchange rate policies to increase stock market patronage, minimize transaction costs, and mitigate the market uncertainties.
\end{abstract}

Keywords: market liquidity, stock return, Nigerian Stock Exchange market

\section{INTRODUCTION}

A highly liquid and functional stock exchange market serves as one of the major determinants for economic growth, high productivity, and development. The major issue that investors consider in investment decision in different stock exchange markets across the globe is stock liquidity (the ease of selling the stock immediately after purchasing it, without lowering the price or incurring transaction costs).

The challenges of unpredictable stock return cut across investors in developed, developing, and emerging stock markets. Kahuthu (2017) claimed that most Africa countries stock market returns were unpredictable and declined from the targeted returns due to the illiquid stock of the Africa stock markets. For instance, despite substantial growth in the Nigerian Stock Exchange market, most investors in this market still suffered declined in stock return. It was due to the problem of low liquidity resulting from disparity in bidask spread, high cost of trading, unstable exchange and inflation rates, brokerage commissions, low frequency trading, information and disclosure deficiencies, poor supervision by regulatory authorities, global financial crisis, and political instability (Okoye, Modebe, Taiwo, \& Okorie, 2016; Popoola, Ejemeyovwi, Alege, Adu, \& Onabote, 2017).

Furthermore, Ariwa, Ani, Onyele, Ekeleme, and Okwuchukwu (2017) stressed that the Nigerian Stock Exchange market lacked the liquidity and efficiency that would ensure availability of long-term funds to users in Nigeria at affordable rates. Various studies outside Nigeria (Akram, 2014; Alnaif, 2014; Amihud, Hameed, Kang, \& Zhang, 2015; Assefa \& Mollick, 2014; Azar, 2014; Demirgünes, 2016; Kahuthu, 2017; Shammakhi \& Mehrabi, 2016) have examined the link between market liquidity and stock return. These studies use firm financial leverage, firm size, 
and firm profitability as determinants for stock return. However, they fail to consider how systematic risk is associated with macroeconomic variables (exchange rate and inflation rate) in influencing stock return. This serves as variables gap in the studies outside Nigeria.

Then, studies on market liquidity and stock return within Nigeria (Ariwa et al., 2017; Onoh, 2016; Onoh, Ibekwe, Onoh, \& Egbo, 2017; Onoh, Ukeje, \& Nkama, 2017) do not consider exchange rate and inflation rate as determinant factors for stock return. These studies use market turnover as a measure for stock liquidity. It is a wrong measure of stock liquidity. They wrongly measure market turnover as the ratio of market capitalization to gross domestic product. Studies such as Abdullahi, Lawal, and Etudaiye-Muhtar (2011), Akram (2014), Assefa and Mollick (2014), Azar (2014), and Bala and Hassan (2018) have established that ratio of market capitalization to gross domestic product only depicts stock market size, not market turnover. Therefore, it is inappropriate of those studies in Nigeria to employ the ratio of market capitalization on the gross domestic product to measure market turnover. Hence, this study measure market turnover as a ratio of the value traded on market capitalization and stock traded volume for stock liquidity. This adds the variable measurement gap.

Relatively, Ariwa et al. (2017), Onoh (2016), Onoh et al. (2017a), and Onoh et al. (2017b) suggested that stock return were unpredictable and declined in the Nigerian Stock Exchange market. It was due to the persistent problems of low-frequency trading, high cost of trading, unstable exchange and inflation rates, brokerage commissions, information and disclosure deficiencies, poor supervision by regulatory authorities, global financial crisis, and political instability. Based on these problems as mentioned earlier and gaps identified in the past studies within and outside Nigeria, it motivates this current study to examine the effect of market liquidity, exchange rate and inflation rate on stock return of the Nigerian Stock Exchange market.

This study is built upon Arbitrage Pricing Theory (APT) developed by Ross (1976b). Ross (1976a) addressed the concern and shortcoming of Capital Asset Pricing Model (CAPM). The APT presents stock pricing model linking expected returns to risk. The model relies on three key prepositions. First, the security return can be described by a factor model. Second, there are sufficient securities to diversify away from the idiosyncratic risk. Third, well-functioning security markets do not allow the persistence of arbitrage opportunities. The model involves identifying macroeconomic variables which influence stock risks and returns.

The application of APT enables investors to relax the restrictions associated with CAPM. Consequently, greater freedom is achieved in the development of the model that explains expected return. In APT, the correlation between an asset and the risk factors associated with it is used to predict its returns. This is achieved by combining exogenous macroeconomic variables in a linear manner (Zaheer \& Rashid, 2014). It is worth noting that several macroeconomic factors determine the returns of an asset. Hence, it is upon the stock analyst to select the factors to focus on. According to Alnaif (2014), factor analysis is the widely used method for determining the main factors that influence asset returns in both international and domestic markets. The APT negates the premise that everyone can access a portfolio in satisfying his or her investment needs and suggests a model that explains the drivers of returns.

APT assumes that rational investor holds a welldiversified portfolio. It is only systematic risk the APT takes care of. Consequently, investors are expected to price these factors precisely. In a nutshell, investors who purchase assets which are exposed to these risks expect to be compensated for investing in the assets by the expected returns. In this regard, a factor beta is used to measure an asset's exposure to risks. The following related studies such as Abdullahi (2011), Abdullahi et al. (2011), Assefa and Mollick (2014), Azar (2014) and Bala and Hassan (2018) are built upon this theory.

Stock market liquidity and macroeconomic volatility have been critical issues to the determination of stock market returns on investment in developed, developing, and emerging stock exchange markets. The illiquidity, unstable inflation, and exchange rates volatilities in Nigerian Stock Exchange market have resulted in the loss in investors' confidence, low stock market patronage, and declined in stock return. Based on the importance of stock liquidity across stock markets in any economies, this research investigates the effect of market liquidity on stock return in the Nigerian Stock Exchange. The levels of stock market liquidity, exchange, and inflation rates volatilities of an economy determine stock market returns.

\section{METHODS}

This research adopts ex-post facto research design by relying on a secondary source as the data. The researchers focus on the effect of market liquidity on stock return in the Nigerian Stock Exchange market within 21 years between 1998 and July 2018. Stock market liquidity represents the independent variable measured by stock turnover. Then, the stock return is the dependent variable while exchange rate and inflation rate served as the control variable.

This research uses Auto-regressive Distributive Lag (ARDL) bound test to model the short run and long run effect of market liquidity on stock return of Nigerian Stock Exchange market. The method is adopted for three reasons. First, the bound test is a simple technique that allows the co-integration relationship to be estimated by Ordinary Least Square (OLS) after the lag order of the model is identified. Second, adopting the bound testing method means that pre-test such as unit root is not required. It is because the regressors can be I(0), purely I(1), or 
mutually co-integrated. Third, the long-run and short run parameters of the models can be simultaneously estimated (Haug, 2002).

The functional model in this research is adapted from Kahuthu (2017) who examined the effect of stock market liquidity on stock return in Kenya. The study variables are also based on APT by Ross (1976b). It links the cost of market liquidity and macroeconomic factors with stock return. Therefore, the model specification of Kahuthu (2017) is:

$\mathrm{R}_{\mathrm{ASI}}=\mathrm{f}(\mathrm{BS}, \mathrm{TR})$

$R_{A S I t}=\beta_{o}+\beta_{I} B S_{t}+\beta_{2} T R_{t}+\mu_{t}$

Where,

$\mathrm{R}_{\mathrm{ASIt}}=$ Stock return

$\mathrm{B}_{\mathrm{St}}=$ Bid-ask spread

$\mathrm{T}_{\mathrm{Rt}}=$ Turnover rate

$\mathrm{U}_{\mathrm{t}}=$ Error term

This model is modified to suit the objectives of this study and in line with APT of Ross (1976a, 1976b) which argued that market width as a dimension of liquidity risk and macroeconomic factors were related to stock return. This study controls macroeconomic variables that determine stock return with foreign exchange and inflation rates. This is in line with APT theory and study of Bala and Hassan (2018). Therefore, the model is modified to:

$R_{A S I t}=\partial_{o}+\partial_{1} S T O+\partial_{2} M S F_{t}+\varepsilon_{t}$

In this research, stock turnover is comprised of market turnover and trade volume. It is depicted in Equation (4).

$R_{A S I t}=\partial_{o}+\partial_{1} M T O_{t}+\partial_{2} T V O_{t}+\partial_{3} M S F_{t}+\varepsilon_{t}$

Where;

$\mathrm{R}_{\mathrm{ASIt}}=$ All share index proxied for stock return $\left(\mathrm{ASI}_{\mathrm{t}}-\mathrm{ASI}_{\mathrm{t}-1} / \mathrm{ASIt}-1\right)$

$\mathrm{STO}_{\mathrm{t}}=$ Stock turnover

$\mathrm{MTO}_{\mathrm{t}}=$ Market turnover (value traded/market capitalization)

$\mathrm{TVO}_{\mathrm{t}}=$ Trade volume (number of deals)

$\mathrm{MSF}_{\mathrm{t}}=$ Macroeconomic factors measured by exchange rate (ER) and inflation rate (INF)

Exchange Rate $(E R)=$ Exchange rate as measured by Naira/USD

$\varepsilon_{\mathrm{t}}=$ Error term

The modify model is extended to ARDL bound test model to adjust with the feature of the study variables. The ARDL model specifications of the determinant of stock return (All Share Index (ASI)) is:
$\Delta \ln \mathrm{ASI}=\partial_{0}+\partial_{1} \ln \mathrm{ASI}_{(\mathrm{t}-1)}+\partial_{2} \operatorname{lnMTO}(\mathrm{t-1)}) \partial_{3} \ln \mathrm{TVO}_{(\mathrm{t}-1)}$ $+\partial_{4} \operatorname{lnER}_{(\mathrm{t}-1)}+\partial_{5} \operatorname{lnINF}_{(\mathrm{t}-1)}+\sum_{i=1}^{k} \gamma_{1 i} \Delta \ln A S I_{t-i}+$

$\sum_{i=1}^{k} \gamma_{2 i} \Delta \ln M T O_{t-i}+\sum_{i=1}^{k} \gamma_{3 i} \Delta \ln T V O_{t-i}+\sum_{i=1}^{k} \gamma_{4 i} \Delta \ln E R_{t-i}+$

$\sum_{i=1}^{k} \gamma_{5 i} \Delta \ln I N F_{t-i}+\varepsilon_{t}$

Where,

$\mathrm{K}=$ lag length for the Unrestricted Error-Correction Model (UECM)

$\Delta=$ first differencing operator

$\varepsilon=$ white noise disturbance error term

The co-integrating long-run relationship is estimated using the specification in Equation (6).

$\Delta \ln A S I=\partial_{0}+\partial_{1} \ln A S I_{(t-1)}+\partial_{2} \ln M T O_{(t-1)}+\partial_{3}$
$\ln T V O_{(t-1)}+\partial_{4} \ln F E R_{(t-1)}+\partial_{5} \ln I N F_{(t-1)}+\varepsilon_{t}$

Then, the short-run dynamic model is specified as:

$\Delta l n A S I=\partial_{0}+\sum_{i=1}^{k} \gamma_{1 i} \Delta \ln A S I_{t-i}+\sum_{i=1}^{k} \gamma_{2 i} \Delta \ln M T O_{t-i}+$

$\sum_{i=1}^{k} \gamma_{3 i} \Delta \ln T V O_{t-i}+\sum_{i=1}^{k} \gamma_{4 i} \Delta \ln E R_{t-i}$

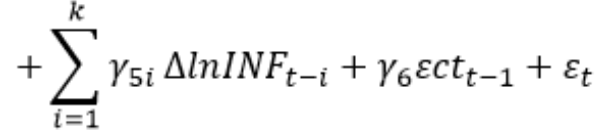

Where,

$\varepsilon c t_{(t-1)}=$ the error correction term lagged for one period $\gamma=$ the coefficient for measuring the speed of adjustment in Equation (5)

Based on extant literature review, the aprior expectations for the study variables are; $\partial_{1}, \partial_{2}, \partial_{3}>$ $0 ; \partial_{4}, \partial_{5}<0$

\section{RESULTS AND DISCUSSIONS}

The result in Table 1 of the preliminary statistics shows that the skewness and kurtosis indicate that the data relating to each variable are normally distributed. These values are within the cut point of $-3,0$ to 3,0 . The researchers find that the parametric statistical analysis is appropriate for this study. The probability of Jarque-Bera statistics is not significant at 5\% level of significance for all the variables. Therefore, the variables are normally distributed. 
Table 1 Preliminary Statistics of Study Variables

\begin{tabular}{llllll}
\hline & LnER & LnMTO & InINF & InTVO & LnASI \\
\hline Mean & 67,126 & 20,138 & 19,137 & 7,6409 & 37,391 \\
Median & 87,105 & 61,158 & 12,220 & 5,2900 & 61,261 \\
Maximum & 93,279 & 94,496 & 72,730 & 18,800 & 14,890 \\
Minimum & 28,375 & 50,459 & 5,4000 & 1,4105 & 21,707 \\
Std. Dev. & 65,008 & 291054 & 17,770 & 5,478 & 503473 \\
Skewness & 0,0152 & 1,5142 & 1,6718 & 1,3633 & 1,3022 \\
Kurtosis & 1,336 & 2,8087 & 2,679 & 1,8654 & 2,3680 \\
Jarque-Bera & 3,577 & 12,690 & 18,082 & 3,7878 & 5,7049 \\
Probability & 0,167 & 0,3018 & 0,1001 & 0,5535 & 0,2507 \\
Sum & 2501,038 & 6,240 & 593,24 & 236,87 & 1,155 \\
Sum Sq. Dev. & 126780,3 & 2,540 & 9473,3 & 900,50 & 7,600 \\
Observation & 252 & 252 & 252 & 252 & 252 \\
\hline
\end{tabular}

(Source: Authors' Computation, 2019)
Table 2 and Table 3 reveal the summary of the unit roots results. From both $\mathrm{ADF}$ and $\mathrm{PP}$ results, some of the variables (TVO, FER, and INF) are integrated at I(1). Meanwhile, others like ASI and MTO are integrated at $\mathrm{I}(0)$ at the absolute term of Mackinnon critical value at 5\% level of significance. Since there is a mixed order of integration, it needs to employ the ARDL method to investigate the co-integration properties and dynamic effect among the variables. The asterisk in Table 2 and Table 3 show that ASI and MTO are stationary at level i.e I(0). Meanwhile, TVO, FER and INF are stationary at first difference I(1).

Table 4 examines the existence of multicollinearity among the variables. The correlation coefficient is less than 0,5 for all the variables measured. It shows that there is no existence of multicollinearity among the variables. Furthermore, the result of the Variance Inflation Factor (VIF) shows that the values of $2,67,1,76,1,82,1,13$, and 2,90 for MTO, TVO, ER, INF, and ASI respectively are less than 5. Therefore, there is no problem of multicollinearity in the model.

Table 2 Augmented Dickey Fuller (ADF)

Unit Root Results

\begin{tabular}{|c|c|c|c|c|c|c|}
\hline Variables & ADF@Level & $\begin{array}{l}\text { Order of } \\
\text { Integration }\end{array}$ & P-value & $\begin{array}{l}\text { ADF @ first } \\
\text { difference }\end{array}$ & P-value & $\begin{array}{l}\text { Order of } \\
\text { Integration }\end{array}$ \\
\hline LnASI & $5,36^{* * *}$ & $\mathrm{I}(0)$ & 2,97 & 8,16 & 3,98 & - \\
\hline LnMTO & $4,32 * * *$ & $\mathrm{I}(0)$ & 2,97 & 6,63 & 3,98 & - \\
\hline LnTVO & 1,57 & $\mathrm{I}(0)$ & 2,97 & $4,67 * * *$ & 3,98 & $1(1)$ \\
\hline LnER & 2,34 & $\mathrm{I}(0)$ & 2,97 & $4,99 * * *$ & 3,98 & $1(1)$ \\
\hline LnINF & 0,11 & $\mathrm{I}(0)$ & 2,97 & $4,96^{* * *}$ & 3,98 & $1(1)$ \\
\hline
\end{tabular}

(Source: Authors' Computation, 2019)

Table 3 Philip Perron (PP) Unit Root Results

\begin{tabular}{lcccccc}
\hline Variables & PP @ Level & $\begin{array}{l}\text { Order of } \\
\text { Integration }\end{array}$ & P-value & $\begin{array}{l}\text { PP @ first } \\
\text { difference }\end{array}$ & P-value & $\begin{array}{l}\text { Order of } \\
\text { Integration }\end{array}$ \\
\hline LnASI & $5,98^{* * *}$ & $\mathrm{I}(0)$ & 3,22 & 9,51 & 4,14 & - \\
LnMTO & $4,88^{* * *}$ & $\mathrm{I}(0)$ & 3,22 & 7,63 & 4,14 & - \\
LnTVO & 1,99 & $\mathrm{I}(0)$ & 3,22 & $4,97 * * *$ & 4,14 & $1(1)$ \\
LnFER & 2,94 & $\mathrm{I}(0)$ & 3,22 & $5,68^{* * *}$ & 4,14 & $1(1)$ \\
LnINF & 1,77 & $\mathrm{I}(0)$ & 3,22 & $5,10^{* * *}$ & 4,14 & $1(1)$ \\
\hline
\end{tabular}

(Source: Authors' Computation, 2019)

Table 4 Correlation Coefficients for Multicollinearity Test

\begin{tabular}{|c|c|c|c|c|c|c|}
\hline Variables & MTO & TVO & ER & INF & ASI & Variance Inflation Factor (VIF) \\
\hline MTO & 1 & & & & & 2,67 \\
\hline TVO & 0,32 & 1 & & & & 1,76 \\
\hline ER & 0,24 & 0,155 & 1 & & & 1,82 \\
\hline INF & $-0,132$ & $-0,350$ & 0,341 & 1 & & 1,13 \\
\hline ASI & 0,233 & $-0,410$ & 0,312 & $-0,410$ & 1 & 2,90 \\
\hline
\end{tabular}

(Source: Authors' Computation, 2019) 
The result of the ARDL in Table 5 shows that MTO in two periods lag has a positive and significant effect on ASI at 5\% level of significance. Moreover, ER and INF in two periods lag have a negative and significant effect on ASI except for TVO that is insignificant at 5\% level of significance. The MTO is significant at $5 \%$ level of significance with a positive coefficient of 0,21112 . It implies that for every $1 \%$ change in MTO, ASI will increase by $2,1 \%$. It indicates that MTO significantly affects stock return in the Nigerian Stock Exchange market at 5\% level of significance. This finding is in line with Leirvik, Fiskerstrand, and Fjellvikås, (2017), Kganyago and Gumbo (2015), Shammakhi and Mehrabi (2016), Onoh (2016), Onoh et al. (2017a), Kahuthu (2017), Kudryavtsev (2017). They agreed that MTO had a positive and significant effect on stock return. Meanwhile, Udoka, Nya, and Bassey (2018) and Shammakhi and Mehrabi (2016) had different findings.

Conversely, TVO as one the measure of stock liquidity shows the opposite effect but insignificant on ASI with a negative coefficient of $-0,006264$. It implies that for every $1 \%$ change in TVO, ASI will decrease by $0,6 \%$. It shows that TVO does not significantly affect stock return in the Nigerian Stock Exchange market at 5\% level of significance. This finding is consistent with the Akram (2014), Amihud et al. (2015), Assefa and Mollick (2014), Azar (2014), Demirgünes (2016) and Ariwa et al. (2017) but it is not in line with Shammakhi and Mehrabi (2016), Onoh (2016), Onoh et al. (2017a), Kahuthu (2017) and Kudryavtsev (2017).

Moreover, ER and INF have a negative and significant effect on ASI at 5\% level of significance. It indicates that ER and INF reduce the value of stock return. These findings are consistent with John (2019) and Jepkemei (2017). However, it is not in line with Kolapo, Oke, and Olaniyan (2018). In addition, the finding shows that short run and long run effect exist among the variables. The finding is consistent with APT that systematic macroeconomic risks and stock liquidity cost determine stock market returns.

Furthermore, the value of adjusted R2 explains that $53 \%$ of the variation in ASI is explained by the independent variables used in the model. The value of F-statistics for the model is statistically significant at $5 \%$ level of significance. Therefore, the model used is considered to be fit since the Prob. (F-statistic) is less than $5 \%$ level of significance. Moreover, the value of Durbin Watson (DW) is 1,92 approximately 2,0 for the model. It shows evidence of no serial correlation.

Table 5 Estimating ARDL

Dependent Variable: ASI

Method: ARDL

\begin{tabular}{|c|c|c|c|c|}
\hline Variable & Coefficient & Std. Error & t-Statistic & Prob.* \\
\hline LnASI (-1) & 0,033288 & 0,054230 & 0,613819 & 0,5485 \\
\hline LnASI (-2) & 1,824623 & 0,505229 & 3,591687 & 0,0027 \\
\hline LnMTO(-1) & 0,445524 & 0,392402 & 1,135376 & 0,2740 \\
\hline LnMTO (-2) & 0,211312 & 0,075020 & 2,816731 & 0,0051 \\
\hline LnTVO(-1) & 0,252341 & 0,024511 & 0,874532 & 0,2453 \\
\hline $\operatorname{LnTVO}(-2)$ & $-0,006264$ & 0,075006 & $-0,083512$ & 0,9335 \\
\hline $\operatorname{LnER}(-1)$ & $-0,000539$ & 0,001582 & $-0,340951$ & 0,7390 \\
\hline $\operatorname{LnER}(-2)$ & $-0,213025$ & 0,053421 & $-3,987677$ & 0,0001 \\
\hline $\operatorname{LnINF}(-1)$ & $-6,223775$ & 2,335942 & $-2,664353$ & 0,0081 \\
\hline $\operatorname{LnINF}(-2)$ & $-0,753021$ & 0,036121 & $-3,987677$ & 0,0341 \\
\hline $\mathrm{C}$ & 3,872067 & 1,266883 & 3,056360 & 0,0091 \\
\hline R-squared & 0,636562 & \multicolumn{2}{|c|}{ Mean dependent var } & 14292,06 \\
\hline Adjusted R-squared & 0,526452 & \multicolumn{2}{|c|}{ S.D. dependent var } & 15187,12 \\
\hline S.E. of regression & 904,6685 & \multicolumn{2}{|c|}{ Akaike info criterion } & 16,48614 \\
\hline Sum squared resid & $2,82 \mathrm{E}+08$ & \multicolumn{2}{|c|}{ Schwarz criterion } & 16,61676 \\
\hline Log-likelihood & $-2922,533$ & \multicolumn{2}{|c|}{ Hannan-Quinn criter. } & 16,53810 \\
\hline F-statistic & 12,25629 & \multicolumn{2}{|c|}{ Durbin-Watson stat } & 1,958651 \\
\hline Prob(F-statistic) & 0,006521 & & & \\
\hline
\end{tabular}

*Note: p-values and any subsequent tests do not account for model 
Table 6 ARDL Bounds Test

Null Hypothesis: No long-run relationships exist

\begin{tabular}{lcc}
\hline Test Statistic & Value & $\mathrm{K}$ \\
\hline F-statistic & 12,703629 & 4 \\
\hline Critical Value Bounds & \\
\hline Significance & I0 Bound & I1 Bound \\
\hline $10 \%$ & 2,72 & 3,77 \\
$5 \%$ & 3,23 & 4,35 \\
$2.5 \%$ & 3,69 & 4,89 \\
$1 \%$ & 4,29 & 5,61 \\
\hline
\end{tabular}

The result of ARDL bound test in Table 6 shows that there are long run relationships between the variables. Since the F-statistics is greater than the upper bound of Pesaran critical value $(3,77,4,35$, 4,89, and 5,61), it implies that there is a significant long run relationship among the variables. From the ARDL bounds test output, F-statistics is more in the upper bound value $(12,703629>4,35)$ at $5 \%$ level of significance. Therefore, the variables can be said to move in the same direction in the long run.

The error correction factor measures the speed of adjustment from short run disequilibrium to the long run path. The value of the error correction term is $-0,418(41,8 \%)$. It satisfies the negativity condition of the framework. The validity is also confirmed by its statistical significance at 5\% (t statistics $=-3,652718$ $<0,0084$ or P-value of $0,0211<0,05)$. Therefore, the rate at which short disequilibrium is corrected to the long period is approximately $42 \%$. It also shows that all the variables are statistically significant as their respective t-statistics and their probability values are less than 0,05 except TVO (number of stock dealing). The result can be seen in Table 7 .

The outcome of the serial correlation, normality, and heteroscedasticity tests are presented in Table 8 . The results indicate that the model passes all the tests. It implies that it has a correct functional form. Its residuals are serially uncorrelated and normally distributed. This conclusion is from the P-values of the diagnostic tests.

Table 7 ARDL Short Run Dynamic

Co-efficient Result

Cointegrating Form

\begin{tabular}{lllll}
\hline Variable & Coefficient & Std. Error & t-Statistic & Prob. \\
\hline $\mathrm{D} \ln (\mathrm{MTO})$ & 0,007977 & 0,052245 & 0,152683 & 0,8787 \\
$\mathrm{D} \ln (\mathrm{TVO})$ & 0,219289 & 0,051390 & 4,267139 & 0,0000 \\
$\mathrm{D} \ln (\mathrm{FER})$ & 0,213025 & 0,053421 & 3,987677 & 0,0001 \\
$\mathrm{D} \ln (\mathrm{INF})$ & 6,223775 & 2,335942 & 2,664353 & 0,0081 \\
CointEq(-1) & $-0,4184$ & 0,006958 & $-3,652718$ & 0,0084
\end{tabular}

Long Run Coefficients

\begin{tabular}{lllll}
\hline Variable & Coefficient & Std. Error & t-Statistic & Prob. \\
\hline Dln(MTO) & 0,341212 & 0,056020 & 3,576742 & 0,0332 \\
DLnTVO & $-0,306251$ & 3,075006 & $-0,052912$ & 0,1643 \\
DLnFER & $-0,634022$ & 0,087426 & $-4,782677$ & 0,0501 \\
DLnINF & $-4,679045$ & 4,093942 & $-3,890351$ & 0,0381 \\
C & 3,872067 & 1,266883 & 4,436982 & 0,0211 \\
\hline
\end{tabular}

(Source: Authors' Computation, 2019) 
Table 8 ARDL Model Diagnostic Tests

\begin{tabular}{ll}
\hline Tests & Prob. \\
Serial Correlation-LM test & 0.167 \\
Normality test & 0.873 \\
Heteroscedasticity & 0.570 \\
\hline
\end{tabular}

(Source: Authors' Computation, 2019)

\section{CONCLUSIONS}

This research concludes that stock turnover positively and significantly influences stock return. Meanwhile, trade volume, exchange rate, and inflation rate affect stock return in Nigerian Stock Exchange market negatively. Empirical studies on market liquidity and stock return provide evidence of the link between the two variables. Nevertheless, most of the studies on market liquidity in developed countries have used bid-ask spread as the measure for market liquidity. Several literatures have established that apart from bid-ask spread, stock turnover and trade volume can also be variables for measurement of market liquidity, especially in developing and emerging stock market, which most past studies ignore. Similarly, it seems that past studies on market liquidity and returns do not use inflation and foreign exchange rates as control variables influencing stock return in Nigeria in which this current study includes as the control variables.

This research focuses on Nigerian Stock Exchange market among other developing, and emerging stock exchange market thereby limits the findings and conclusion only on Nigerian Stock Exchange market. It cannot be generalized to cover other developing and emerging stock market. This study does not use all the variables measuring stock liquidity because of the nature of the Nigerian Stock Exchange market. Based on the findings and conclusion, the study suggested the following policy recommendations. First, Nigerian Stock Exchange market regulators should implement stock market policies such as demutualization structure and transparent policy. It will increase stock market patronage and minimize transaction costs and uncertainty in the market to encourage upturn in stock turnover, which increases stock return. Second, it is suggested that the stock investors adopt trading volume based criterion in their investment decision to enable an increase of higher returns on their investment. Third, there is a need for stock market regulators to loose some stringent registration and operating procedures to enable more investors and organizations to participate fully in the market. Fourth, Central bank of Nigeria should employ deflationary fiscal and monetary policies to manage inflation and avoid higher rates of inflation that may reduce the value of stock return in Nigerian Stock Exchange market. Fifth, Central bank of Nigeria should also employ adaptive method stabilization in exchange rate policy to achieve exchange rate stability.

Moreover, further research should be carried out on comparative studies among developing and emerging stock market on market liquidity and returns. Similarly, further study should include other variables like Amivest liquidity measure, Amihud illiquidity measure, price impact measure of liquidity, and return to a volume measure of liquidity depending on the characteristics of their stock market.

\section{ACKNOWLEDGEMENT}

I appreciate the unquantifiable effort of my supervisor, Dr. I. B. Abdullahi (An Associate Professor of Finance), who adviced and mentored me on this research.

\section{REFERENCES}

Abdullahi, I. B. (2011). Sectoral analysis of risks and returns of the quoted firms in the Nigerian capital market (Unpublished Ph.D. Thesis). University of Ilorin.

Abdullahi, I. B., Lawal, W. A., \& Etudaiye-Muhtar, O. F. (2011). The effects of firm size on risk and return in the Nigerian Stock Market: A sectoral analysis. British Journal of Economics, 1(2),1-10.

Akram, N. (2014). The effect of liquidity on stock returns: An evidence from Pakistan. IOSR Journal of Business and Management, 16(2), 66-69.

Alnaif, K. L. (2014). Stock liquidity determination evidence from Amman Stock Exchange. Asian Economic and Financial Review, 4(12), 1894-1905.

Amihud, Y., Hameed, A., Kang, W., \& Zhang, H. (2015). The illiquidity premium: International evidence. Journal of Financial Economics, 117(2), 350-368.

Ariwa, F. O., Ani, O. I., Onyele, K. O., Ekeleme, I. J., \& Okwuchukwu, O. (2017). Impact of stock market liquidity and efficiency on performance of the manufacturing sector in Nigeria (1985-2014). International Journal of Economics and Financial Management, 2(1), 71-82.

Assefa, T. A., \& Mollick, A. V. (2014). African stock market returns and liquidity premia. Journal of International Financial Markets, Institutions and Money, 32(September), 325-342.

Azar, S. A. (2014). The determinants of US stock market returns. Open Economics and Management Journal, 1(1), 1-13.

Bala, S. A. R., \& Hassan, A. (2018). Exchange rate and stock market interactions: Evidence from Nigeria. Arabian Journal of Business and Management Review, 8(1), 1-5.

Demirgüneş, K. (2016). The effect of liquidity on financial performance: Evidence from Turkish retail industry. International Journal of Economics and Finance, 8(4), 63-79.

Haug, A. A. (2002). Temporal aggregation and the power of cointegration tests: A Monte Carlo study. Oxford Bulletin of Economics and statistics, 64(4), 399-412. 
Jepkemei, B. (2017). The impact of inflation on stock market liquidity: A case of Nairobi Securities Exchange, Kenya. International Journal of Economics, Commerce and Management, 5(1), 319-350.

John, E. I. (2019). Effect of macroeconomic variables on stock market performance in Nigeria. Journal of Economics, Management and Trade, 22(6), 1-14.

Kahuthu, L. W. (2017). The effect of stock market liquidity on stock returns of companies listed on Nairobi Securities Exchange (Thesis). Strathmore University.

Kganyago, T., \& Gumbo, V. (2015). An empirical study of the relationship between money market interest rates and stock market performance: Evidence from Zimbabwe (2009-2013). International Journal of Economics and Financial Issues, 5(3), 638-646.

Kolapo, F. T., Oke, M. O., \& Olaniyan, T. O. (2018). Unravelling the impact of macroeconomic fundamentals on stock market performance in Nigeria: An ARDL-bound testing approach. Journal of Economics, Management and Trade, 21(3), 1-15.

Kudryavtsev, A. (2017). The effect of stock return sequences on trading volumes. International Journal of Financial Studies, 5(4), 1-15.

Leirvik, T., Fiskerstrand, S. R., \& Fjellvikås, A. B. (2017). Market liquidity and stock returns in the Norwegian stock market. Finance Research Letters, 21(May), 272-276.

Okoye, L. U., Modebe, N. J., Taiwo, J. N., \& Okorie, U. E. (2016). Impact of capital market development on the growth of the Nigerian economy. Research Journal of Financial Sustainability Reporting, 1(1), 24-32.

Onoh, J. O. (2016). The effect of stock market liquidity on daily returns in the Nigerian capital market. IIARD International Journal of Banking and Finance Research, 2(1), 54-72.
Onoh, J. O., Ibekwe, F. C., Onoh, U. A., \& Egbo, B. U. (2017a). Measuring daily stock market returns using market capitalization ratio in Nigeria. GOUNI Journal of Management and Social Sciences, 4(2), 188-203.

Onoh, J. O., Ukeje, O. S., \& Nkama, N. O. (2017b). Trading volume and market turnover in the Nigerian capital market: Implications to stock market returns. IIARD International Journal of Economics and Business Management, 3(1), 91-107.

Popoola, O. R., Ejemeyovwi, O. J., Alege, O. P., Adu, O., \& Onabote, A. A. (2017). Stock market and economic growth in Nigeria. International Journal of English Literature and Social Sciences (IJELS), 2(6), 97106.

Ross, S. A. (1976a). Return, risk and arbitrage. In I. Friend \& J. Bicksler (Eds.), Risk and return in finance. Cambridge, MA: Ballinger.

Ross, S. A. (1976b). The arbitrage theory of capital asset pricing. Journal of Economic Theory, 13(3), 341360.

Shammakhi, H. R., \& Mehrabi, A. (2016). Study the effect of liquidity of stock on stock returns in the companies listed in Tehran Stock Exchange. International Journal of Economics, Commerce and Management, 4(12), 423-434.

Udoka, C. O., Nya, M. J., \& Bassey, J. G. (2018). The effect of macroeconomic determinants of stock price movements in Nigeria. International Journal of Research-Granthaalayah, 6(1), 203-218.

Zaheer, A. L. A. M., \& Rashid, K. (2014). Time series Analysis of the relationship between macroeconomic factors and the stock market returns in Pakistan. Journal of Yaşar University, 9(36), 6361-6370. 